\title{
Natural Capital: Essence, Types and Evaluation Procedure
}

\author{
Submitted 02/03/20, $1^{\text {st }}$ revision $11 / 04 / 19,2^{\text {nd }}$ revision $13 / 05 / 19$, accepted $20 / 07 / 20$
}

\author{
H.O. Partyn ${ }^{1}$, A.H. Zahorodniy ${ }^{2}$, L.M. Pylypenko ${ }^{3}$, O.V. ${ }^{4}$ Didukh \\ Abstract:
}

Purpose: The article investigates the nature of the enterprise's natural capital and its classification.

Design/Methodology/Approach: The study is based on the hypothesis that the natural capital used in the economic activity of an enterprise influences the value of the enterprise, and therefore such capital should be reflected in public reporting to inform the stakeholders. The article has used the dialectical method of cognition to establish the essence of the concept of the natural capital of the enterprise and its relationship with other similar categories, classification of natural capital of the enterprise, determination of the main stages of formation of information necessary for the assessment of the natural capital, and analysis and synthesis to highlight the key elements of natural capital information that wellknown companies display in their integrated reporting. The subject of the study was the integrated reporting of four big companies operating in Ukraine (three multinational and one national).

Findings: Approaches to the information and analytical support of the estimation of the natural capital of the enterprise with consideration to costs and benefits from its use are analyzed, the main stages of formation of the information necessary for its evaluation are determined.

Practical Implications: The results are interesting from the theoretical and practical aspects to be applied for the improvement of the enterprise natural capital management and reporting.

Originality/Value: The paper contains a formalized approach to the estimation of the natural capital of the enterprise, based on the method of cash flow discounting.

Keywords: Natural capital of the enterprise, type of the enterprise, value of the enterprise.

JEL: M40, Q01.

Paper Type: Research Paper.

\footnotetext{
${ }^{l}$ Department of Finance, Lviv Polytechnic National University, Ukraine. e-mail: halyna.o.partyn@lpnu.ua

${ }^{2}$ Department of Accounting and Analysis, Lviv Polytechnic National University, Ukraine. e-mail: anatolii.h.zahorodnii@lpnu.ua

${ }^{3}$ Department of Accounting and Analysis, Lviv Polytechnic National University, Ukraine. e-mail: liubomyr.m.pylypenko@lpnu.ua

${ }^{4}$ Department of Finance, Lviv Polytechnic National University, Ukraine. e-mail: oksana.v.didukh@lpnu.ua
} 


\section{Introduction}

The processes of economic growth are accompanied by the involvement in the production of increasing volumes and new kinds of natural resources. Even with the entry of individual countries into the post-industrial stage of development, the cost of raw materials remains substantial on a global scale. Virtually all branches of material production are based on raw materials. Natural resources are used in production processes to create many goods, and they are also a source for meeting the different needs of people.

Natural resources and processes that participate in the formation of value in the enterprise contribute to income and profit form a separate component of its capital natural capital. Scientists and practitioners emphasize that the scale and irrational use of natural capital has led to the fact that in the 21 st century this capital will be as important for doing business as in the 20st century was to ensure the activity of economic entities with sufficient amounts of financial capital. Therefore, today there is a need for quantitative and, where possible, financial evaluation of natural capital not only of individual countries but also of specific economic entities, comparison of the volumes of its use with the results obtained. Particularly urgent is the problem of objectively reflecting the volume of natural capital for enterprises belonging to resource-oriented types of economic activity, in particular agricultural enterprises, forestry, oil and gas companies, enterprises of the extractive industry, etc. The value of the most important assets of these entities - land, forests, pastures, mineral resources - do not reflect in their financial statements, which degrades their resource potential and investment attractiveness (Atkinson, 2015).

Against this background, the issues of the nature, composition and valuation of the natural capital of the enterprise need further research, especially in the context of the need for its objective reflection in the integrated reporting.

\section{Theoretical Background}

The research is based on scientific results from:

- problems of natural capital and its importance for ensuring the sustainable development of the economy, covered in the writings of Atkinson (2015), Barker and Mayer (2017), Vegera (2015), Veklic (2004), Kostanza (1992), Kriven (2006), Lushchik (2019), Farley (2018), and Shlapak (2010);

- information support for the formation of macroeconomic indicators in the part of natural capital on the basis of data generated in the accounting system of economic entities, substantiated by Malyha and Zamula (2010);

- problems and methods of estimation of natural capital of regions and enterprises investigated in the works of Fiedor (2017), Burkinsky and Goryachuk (2013), Bouleev and Rassuzhday (2015), Czaja (2013), Melnyk and Kogdenko (2016). 


\section{Results}

\subsection{The Essence of Natural Capital and its Types}

The concept of natural capital has been actively researched by scientists in the process of ecological economy development, during studying the relationship between human, society, economy and nature. Scientists view natural capital as a rich variety of economically valuable resources and processes that are provided to people free of charge (DesRoches, 2018). Human society depends on the flow of goods and services of natural origin. Owing to the mismanagement of natural capital for many centuries, today there is a situation where the planet's natural capital is depleted faster than it can recover and waste enters the environment to an extent greater than it can be absorbed by nature. Such depletion of natural capital reduces not only the ability of nature to self-renew, but also the volume of raw materials and the flow of ecosystem services (ecosystem ecological functions) required for economic production.

Depending on the area covered, transnational natural capital, natural capital of a country, region, and natural capital of an individual entity can be distinguished, which are specific objects of research for modern science as important factors for ensuring sustainable economic development. In particular, the effective management of the natural capital of individual enterprises is an important basis for successful business management and, consequently, for the development of the state's economy. At the same time, the management of many companies does not have sufficient information about the level of dependence of their business on natural capital and how their activities interact with the environment. In addition, corporate reporting does not properly address the benefits and costs of the enterprise from the use of natural capital, as well as the environmental impact of these processes and the potential for sustainable development of the economy and humanity as a whole.

Given the urgency of this issue, the Integrated Reporting Committee has provided disclosure in the entity's reporting of data on six types of capital: financial, industrial, human, intellectual, social and reputational, natural. The International Standard on Integrated Reporting provides a rather generalized definition of the concept of an enterprise's natural capital as all renewable and non-renewable natural resources and processes that enable it to create goods or provide services and, on that basis, to support the enterprise's past, present and future prosperity. Such natural resources include, in particular, air, water, land, minerals and forests, biodiversity and ecosystem health.

Since the theory of natural capital is now in its initial stages of development, there is a need to clarify the concept of natural capital of the enterprise. To do this, first of all, it is necessary to distinguish between the concepts of natural environment; natural potential, natural resources and natural capital of the enterprise (Figure 1). 
Figure 1. Conciliation of concepts "Natural environment of the enterprise", "Natural potential of the enterprise", "Natural resources of the enterprise" and "Natural capital of the Enterprise"

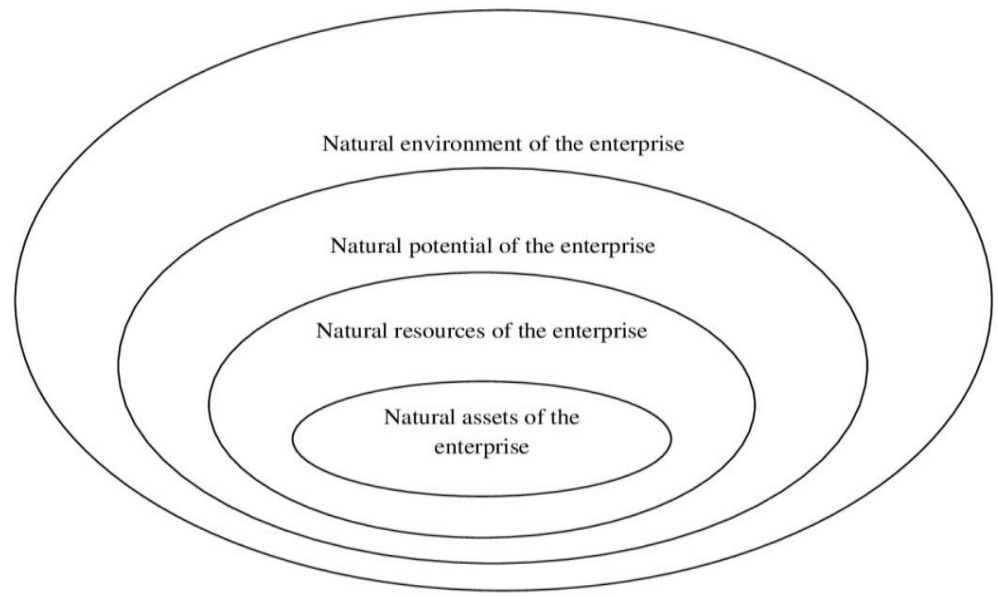

Source: Based on (Burkinsky, 2013)

The natural environment of the enterprise - these are all components of the environment of natural origin, which collectively form the basis of the enterprise functioning. The natural potential of an enterprise encompasses the potential (accessible and inaccessible at the moment) for the use in its business activities of the objects and forces of nature, given the current level of development of science and technology. Natural resources of the enterprise are those objects and forces of nature that are available at this time for use and involvement in its economic turnover. Those objects and forces of nature that are directly involved in the economic turnover of the enterprise and participate in the process of creating value, providing economic benefits, form its natural capital.

Therefore, the natural capital of an enterprise can be defined as the volume of natural resources that participate in the value creation process and are a source of economic benefits of enterprise in the form of receiving cash income, income, and profit during their useful life.

With the development of scientific and technological progress, the natural capital of an enterprise may change, in particular, on the basis of new types of natural resources usage or the resources' new technologies use. In addition, because an enterprise operates in a particular territory, the natural capital of the enterprise may also change as a result of the change in the natural capital of the region or country. The analysis of literary sources (Atkinson, 2015; Barker, 2017; Kriven, 2006; Lushchik, 2019; Shlapak, 2010; Malyha, 2010) makes it possible to classify natural resources that form the natural capital of an enterprise according to the system of features, in particular, by physical composition, ability to reproduce, form of 
expression, role in the process of value creation, the nature of participation in the value creation process, belonging to the enterprise (Figure 2).

\subsection{Information and Analytical Support for the Assessment of the Natural Capital of an Enterprise}

The formation of value in many enterprises depends on the availability of natural resources and products of natural origin, such as minerals, energy, sun, wind or water, as well as the natural processes associated with water treatment, pollination of plants, protection of soil from erosion, etc. Many business models are based on natural capital, but the enterprise's reporting does not reflect its volume and value from usage. Analysis of the content of the integrated reporting of well-known national and world companies, in particular South African mining company Merafe Resources Limited, Swiss chemical company GLARIANT, Ukrainian energy company DTEK, South African chemical company AECI GROUP, which usually covers the following information on natural capital:

$>$ the content of major issues related to their natural capital elements usage, in particular the availability of energy and water, climate change, waste and emissions, safety and health of workers and investment in new technologies to improve energy efficiency and reduce emissions;

$>$ the content of measures of the enterprise natural capital support of the country regions such as reducing dependence on fuel, reducing the level of waste and increasing the volume of their processing, protection of biodiversity and ecosystems and volumes of restoration of renewable resources;

$>$ the amount of environmental fines paid;

$>$ volumes of extraction of natural minerals.

It should be noted that the International Standard on Integrated Reporting does not provide a clear algorithm for reporting information on the types of capital of an enterprise, in particular, on natural capital. Therefore, in the integrated reporting of many enterprises, information on natural capital is mostly descriptive, reveals the use of natural resources or harmful emissions in natural units and does not allow evaluating and comparing the level of impact of different components of natural capital on the environment and on the formation of value. This leads to the need to justify the methods of economic (monetary) assessment of natural capital of the enterprise.

It should be noted that in the economic literature, the amount of capital of an enterprise is determined by the total amount of money, in tangible and intangible forms, invested in its assets (property), which bring income and profit. Natural resources that an enterprise uses in business processes also generate revenue and profits, but they are not a consequence of its previous economic activity and are not related to investing (other than spending on exploration and obtaining special permits and licenses). Therefore, the value of the natural capital of an enterprise 
cannot be estimated as the sum of funds invested in their formation. It is also difficult to estimate the natural capital of an enterprise on the basis of market prices for natural resources due to the absence of such prices for a certain type of enterprise's resources. Therefore, it is advisable to evaluate the natural capital of an enterprise on the basis of identification and determination of the amount of benefits and costs of the enterprise from the use of natural resources in the process of value formation.

Figure 2. Classification of natural resources that forms natural capital of the Enterprise.

\begin{tabular}{|c|c|}
\hline Types of natura & ources that form the natural capital of the enterprise \\
\hline \multirow{2}{*}{ By physical content } & $\begin{array}{l}\text { Objects and systems of animate and inanimate nature (minerals, } \\
\text { water, soil, fauna, flora) }\end{array}$ \\
\hline & $\begin{array}{l}\text { Natural processes (ecosystems assimilation capacity, climate } \\
\text { regulation, air purification) }\end{array}$ \\
\hline \multirow{2}{*}{$\begin{array}{l}\text { By the ability to } \\
\text { reproduction }\end{array}$} & Non-reproducible natural resources (minerals) \\
\hline & $\begin{array}{l}\text { Reproductive natural resources (ecosystem restoration, soil } \\
\text { fertility) }\end{array}$ \\
\hline \multirow{2}{*}{$\begin{array}{l}\text { By the form of } \\
\text { manifestation in } \\
\text { the process of } \\
\text { value creation }\end{array}$} & Natural resources (minerals, land, forests) \\
\hline & Intangible natural resources (unique landscape, climate, clean air) \\
\hline \multirow{2}{*}{$\begin{array}{l}\text { By role in the value } \\
\text { creation process }\end{array}$} & $\begin{array}{l}\text { Basic (essential, critical) natural resources (involved in major } \\
\text { value creation processes at the enterprise) }\end{array}$ \\
\hline & $\begin{array}{l}\text { Ancillary natural resources (involved in ancillary value creation } \\
\text { processes at the enterprise) }\end{array}$ \\
\hline \multirow{2}{*}{$\begin{array}{l}\text { By the nature of } \\
\text { participation in the } \\
\text { value creation } \\
\text { process }\end{array}$} & $\begin{array}{l}\text { Active part (directly involved in value creation - carbon } \\
\text { sequestration, water filtration, wind for wind farms) }\end{array}$ \\
\hline & $\begin{array}{l}\text { Passive part (creates the conditions for the implementation of } \\
\text { the value formation processes - minerals, raw materials) }\end{array}$ \\
\hline \multirow{3}{*}{$\begin{array}{l}\text { By belonging to the } \\
\text { enterprise }\end{array}$} & $\begin{array}{l}\text { Own natural resources (belonging to the enterprise on the } \\
\text { property rights) }\end{array}$ \\
\hline & $\begin{array}{l}\text { Borrowed natural resources (used by enterprises under } \\
\text { concession, lease) }\end{array}$ \\
\hline & $\begin{array}{l}\text { Publicly available natural resources (solar, wind, geographic } \\
\text { space, seas, oceans, climatic conditions) }\end{array}$ \\
\hline
\end{tabular}

Source. Own.

In this case, the assessment of the amount of natural capital of the enterprise should include the following:

$>$ creation of a register of natural resources that form the natural capital of the enterprise;

$>$ identification of the benefits generated by the natural resources of the enterprise; measurement in natural units of the volume of these benefits; 
$>$ monetary measurement of the amount of benefits received from the use of natural resources in the process of value creation;

$>$ determining the amount of costs associated with the implementation of maintenance, maintenance and restoration of natural resources of enterprises;

$>$ evaluation of the value of both individual components and the total amount of natural capital of the enterprise (Table 1).

Table 1. The main stages of the information formation needed to assess the natural capital of sn enterprise

\begin{tabular}{|l|l|}
\hline $\begin{array}{l}\text { Stages of the information } \\
\text { formation }\end{array}$ & Stage description \\
\hline $\begin{array}{l}\text { 1. Creating a register of } \\
\text { natural resources of the } \\
\text { enterprise }\end{array}$ & $\begin{array}{l}\text { Identification of the composition and determination of the volume } \\
\text { and quality of natural resources that are owned or used by the } \\
\text { enterprise in the process of value creation, as well as the } \\
\text { possibilities and ways of their recovery and increase }\end{array}$ \\
\hline $\begin{array}{l}\text { 2. Determining the benefits } \\
\text { of an enterprise generated } \\
\text { by natural resources }\end{array}$ & $\begin{array}{l}\text { Identification of the composition of existing and potential benefits } \\
\text { generated by individual types of enterprise natural resources in the } \\
\text { value creation process }\end{array}$ \\
\hline $\begin{array}{l}\text { 3. Measuring the volume of } \\
\text { benefits of an enterprise } \\
\text { generated by natural } \\
\text { resources }\end{array}$ & $\begin{array}{l}\text { Determination of the amount of benefits generated by the } \\
\text { enterprise's natural resources over a period of time (eg, a year) in } \\
\text { natural units. The choice of methods of monetary measurement of } \\
\text { the amount of benefits received. Monetary measurement of the } \\
\text { volume of certain types of benefits received by the enterprise }\end{array}$ \\
\hline $\begin{array}{l}\text { 4. Determining the amount } \\
\text { of enterprise costs } \\
\text { associated with the use of } \\
\text { natural resources }\end{array}$ & $\begin{array}{l}\text { Determination of volume and financial estimation of the enterprise } \\
\text { costs, related to maintenance, support and restoration of natural } \\
\text { resources used in the value formation process }\end{array}$ \\
\hline $\begin{array}{l}\text { 5. Valuation of natural } \\
\text { capital of the enterprise }\end{array}$ & $\begin{array}{l}\text { Valuation of the value of individual components and the total } \\
\text { amount of natural capital of the enterprise }\end{array}$ \\
\hline
\end{tabular}

Source: Formed by the authors.

The Natural Capital Committee (NCC, UK) has identified the types of benefits that society and economic entities receive from the use of natural resources, namely the cultivation of biological (living) flora and fauna objects, use of non-biological (nonliving) elements such as fresh water, minerals, energy resources, etc., ecosystem services for food and raw materials supply, protection against soil erosion, regulation of water runoff, final goods and services that are created in conjunction with other types of capital, such as recreation and recreation areas, drinking water, crops, etc. (Report, 2019).

Among the methodological approaches to the assessment of benefits from natural resources can be distinguished, market, rent, cost, reproduction, based on the assessment of reserves of natural resources, the method of options, alternative cost, total economic value. Characteristics of the essence of these approaches are presented in the works of Burkinskiy and Goryachuk (2013), Fiedor (2017), Melnyk and Kogdenko (2016). 
Enterprises can independently choose the method of estimating the benefits of using natural resources, taking into account the level of their development, versatility and the ability to obtain data for calculations. In addition, the use of natural resources in the process of creating value causes the appearance of certain types of company expenses such as the cost of their care, support and recovery. To value the natural capital of an enterprise, is necessary to compare the amounts of the above benefits and costs and to determine the net benefit in the form of a discounted amount of net cash flows from the use in the process of value creation of natural resources. It should also be noted that the natural capital of an enterprise is shaped by the benefits that the enterprise receives from the use of natural resources. That part of the benefits of using the natural resources of an enterprise received by society contributes increasing the social and reputational capital of this enterprise.

It is advisable to carry out the estimation of the amount of benefits of the enterprise from the use of natural resources in tabular form, which will allow to calculate the cost of benefits that generate individual objects of natural resources and to determine the total value of the benefits received by the enterprise. If an entity receives certain benefits from the simultaneous use of several types of natural resources, then the weighting of the participation of those resources in the formation of value should be used to assess these benefits. An example of determining the expected benefits of a contingent enterprise from the use of natural resources that form its natural capital is presented in Table 2. In this example, it is accepted that the benefit in the form of recreation is formed by the lake $(70 \%)$ and wooded area $(30 \%)$.

Table 2. Expected average annual benefits of enterprise natural resources usage that forms its natural capital

\begin{tabular}{|c|c|c|c|c|c|c|c|c|c|c|c|}
\hline \multirow{3}{*}{$\begin{array}{l}\text { Types of } \\
\text { natural } \\
\text { resources }\end{array}$} & \multicolumn{10}{|c|}{ Benefits of enterprise natural resources } & \multirow{3}{*}{$\begin{array}{l}\text { The total cost } \\
\text { of benefits } \\
\text { received by } \\
\text { the enterprise, } \\
\text { thousand } \\
\text { UAH. }\end{array}$} \\
\hline & \multicolumn{2}{|c|}{ Energy resources } & \multicolumn{2}{|c|}{ Raw materials } & \multicolumn{2}{|c|}{ Pure water } & \multicolumn{2}{|l|}{ Food } & \multicolumn{2}{|c|}{ Recreation } & \\
\hline & $\begin{array}{l}\text { Volum } \\
\text { e thou. } \\
\text { m3 }\end{array}$ & $\begin{array}{l}\text { Amou } \\
\text { nt, } \\
\text { thou. } \\
\text { UAH. }\end{array}$ & $\begin{array}{l}\text { Volume } \\
\text { tons }\end{array}$ & $\begin{array}{l}\text { Amo } \\
\text { unt, } \\
\text { thou. } \\
\text { UAH }\end{array}$ & $\begin{array}{l}\text { Volume, } \\
\text { thou. m3 }\end{array}$ & $\begin{array}{l}\text { Amoun } \\
\text { t, thou. } \\
\text { UAH. }\end{array}$ & $\begin{array}{l}\text { Volume, } \\
\text { tons }\end{array}$ & $\begin{array}{l}\text { Amo } \\
\text { unt, } \\
\text { thou. } \\
\text { UAH }\end{array}$ & $\begin{array}{l}\text { Power, } \\
\text { persons }\end{array}$ & $\begin{array}{l}\text { Amount, } \\
\text { thou. } \\
\text { UAH }\end{array}$ & \\
\hline $\begin{array}{l}\text { Land for } \\
\text { agricultura } \\
\text { l purposes }\end{array}$ & & & & & & & 50 & 2500 & & & 2500 \\
\hline Woodland & 0,6 & 120 & & & & & 4 & 400 & 800 & $\begin{array}{l}1600 \times 0,3 \\
=480\end{array}$ & 1000 \\
\hline $\begin{array}{l}\text { Career of } \\
\text { kaolin } \\
\text { mining } \\
\end{array}$ & & & 980 & 49 & & & & & & & 49 \\
\hline Gas field & 2000 & 1400 & & & & & & & & & 1400 \\
\hline Lake & & & & & 3000 & 30 & & & 800 & $\begin{array}{ll}1600 & \mathrm{x} \\
0,7 & = \\
1120 & \\
\end{array}$ & 1150 \\
\hline Total: & & 1520 & & 49 & & 30 & & 2900 & & 1600 & 6099 \\
\hline
\end{tabular}

Source: Formed by the authors.

The enterprise's natural resources not only generate benefits, but also require expenses for their maintenance, support and recovery. An example of determining the costs of a conventional enterprise for natural resources is presented in Table 3. 
Table 3. Planned annual average costs of the enterprise for the maintenance, support and recovery of natural resources that form its natural capital

\begin{tabular}{|l|l|l|l|l|}
\hline \multirow{2}{*}{ Types of natural resources } & Cost amount, thou. UAH. & \multirow{2}{*}{ Total costs thou. UAH. } \\
\cline { 2 - 5 } & On maintance & On support & On recovery & \\
\hline Land for agricultural purposes & 800 & 200 & 930 & 1930 \\
\hline Woodland & 160 & 30 & 280 & 470 \\
\hline Career of kaolin mining & 15 & 18 & - & 33 \\
\hline Gas field & 170 & 320 & 400 & 890 \\
\hline Lake & 90 & 280 & 350 & 720 \\
\hline Total: & $\mathbf{1 2 3 5}$ & $\mathbf{8 4 8}$ & $\mathbf{1 9 6 0}$ & $\mathbf{4 0 4 3}$ \\
\hline
\end{tabular}

Source: Formed by the authors.

On the basis of Tables 2 and 3, we determine the amount of the net benefit of the contingent enterprise from the use of natural resources in the process of value creation (Table 4).

Table 4. The average annual net profit of an enterprise from the use of natural resources in the process of value creation

\begin{tabular}{|l|l|l|l|l|l|l|}
\hline \multirow{2}{*}{$\begin{array}{l}\text { Costs, } \\
\text { benefits }\end{array}$} & \multicolumn{3}{|l|}{ Amounts of benefits and expenses by types of natural resources, thou. UAH. } \\
\cline { 2 - 7 } & $\begin{array}{l}\text { Land for agricultural } \\
\text { purposes }\end{array}$ & Woodland & $\begin{array}{l}\text { Career of } \\
\text { kaolin mining }\end{array}$ & Gas field & Lake & Total \\
\hline $\begin{array}{l}\text { Amounts of } \\
\text { benefits }\end{array}$ & 2500 & 1000 & 49 & 1400 & 1150 & 6099 \\
\hline $\begin{array}{l}\text { Amounts of } \\
\text { costs }\end{array}$ & 1930 & 470 & 33 & 890 & 720 & 4043 \\
\hline $\begin{array}{l}\text { Amounts of } \\
\text { net benefit }\end{array}$ & 570 & 530 & 16 & 510 & 430 & 2056 \\
\hline
\end{tabular}

Source: Formed by the authors.

In addition, the amount of natural capital of an enterprise is affected by the amount of emissions and discharges of pollutants in the environment that are related to its economic activity. As a result, the enterprise incurs costs in the amount of environmental tax, other payments in accordance with the current legislation of each country. For example, the expected average annual amount of cash payments to a contingent enterprise to compensate for environmental damage will be 165 thousand UAH. It should be noted that the amount of damage caused by an enterprise may be greater than the amount of money paid to it, which will adversely affect the natural capital of the region or country and the potential for its natural capital to increase in the future.

\subsection{Formalization of Natural Capital of the Enterprise's Assessment}

The total amount of natural capital of an enterprise can be estimated on the basis of discounting the expected average annual amount of its net benefit over the period of the useful use of natural resources in the process of value creation. Therefore, the enterprise needs to determine the expected period of use of natural resources in the economic activity and the value of the discount rate. It is recommended to calculate the volume of natural capital of the enterprise (NC) by formula (1): 


$$
N K=\sum_{i=1}^{n} \sum_{j=1}^{k} N P V_{j i}-\sum_{i=1}^{n} E B_{i}
$$

Where:

- NPVij - is the net present value of the benefits that an enterprise receives from an i-type of natural resources in the course of value creation during the $\mathrm{j}$-th period of their use, in thous. UAH;

- EBi - is the expected cost of the enterprise for compensation of damage caused to the environment as a result of its activity in the $\mathrm{j}$-th period of use of natural resources, in thous. UAH;

- $\quad \mathrm{N}-$ is the expected useful life of the enterprise's natural resources and, consequently, the associated costs, in years;

- $\quad \mathrm{K}$ - is the number of types of natural resources of the enterprise that form its natural capital.

Using data from Tables 3 and 4 and value of the compensatory environmental payments volume, we calculate the volume of natural capital of a contingent enterprise. To simplify the calculations, we suppose that the average annual benefits and costs of the enterprise in the process of costing from the use of natural resources will be approximately uniform, the useful life of land, woodland and lake is unlimited, and of the career and gas field will be 10 years. The discount rate is $12 \%$.

The volume of natural capital of the enterprise is calculated by Formula 1 and algorithms for determining the present value of the life annuity and the present value of the annuity lasting 10 years.

$$
\begin{aligned}
& \mathrm{NK}=\left[\frac{570+530+430}{0,12}+(16+510) \cdot\left(\frac{1}{0.12}-\frac{1}{0.12\left(1+0,12+(1+0.12)^{10}\right.}\right)\right]- \\
& -\left[165 \cdot\left(\frac{1}{0,12}-\frac{1}{0,12(1+0,12)^{10}}\right)\right]-165 \cdot\left[\frac{1}{0,12}-\frac{1}{0,12+(1+0,12)^{10}}\right]= \\
& =15722,4-932,4=14790 \text { thousand UAH }
\end{aligned}
$$

The above calculations show that the assessment of natural capital amount of an enterprise requires a variety of information about the composition of natural resources, the benefits they retain and how to evaluate them. Relevant institutions have been set up in a developed country to collect such information. In 2012, a Natural Capital Committee (NCC) was set up in the United Kingdom to provide expert and advisory services on the identification of benefits from natural resources, their economic evaluation and investment in natural capital development (Government's 25 Year Environment Plan, 2019). In April 2018, the Global Natural Fund (GNF) was launched in Germany, implementing a project called Natural Capital for the Company, funded by the Federal Environmental Agency, to form regular seminars and conferences for businesses. In Ukraine, where the problem of 
the depletion of natural capital is extremely acute, the Ministry of Ecology and Natural Resources should focus its activities on the development and implementation of the project in order to ensure the objective assessment of the natural capital volume both at the level of the whole country and individual regions and individual economic entities.

Monetary valuation of the natural capital elements of enterprises provides a number of benefits, the most important of which are:

$>$ possibility of using "cost-benefit" analysis in the process of natural resource management;

$>$ improving the process of analyzing the efficiency of the use of individual elements of the natural capital of the enterprise;

$>$ ability to identify constraints ("hot spots") in the structure of the enterprise's natural capital and in the use of natural resources;

$>$ enhancing transparency of the environmental sustainability of the enterprise and, consequently, reducing its reputational risks to stakeholders;

$>$ improving the quality of coverage of the conditions and consequences of the use of natural capital by the enterprise for society and increasing its social and reputational capital.

\section{Conclusions}

The enterprise's natural capital, corresponding to the amount of natural resources involved in the value creation process, is a source of economic benefits for the enterprise in the form of cash flows, income and profits during their useful life. Natural resources that form the natural capital of an enterprise can be classified by the system of features, among which are their physical composition, ability to reproduce, form of manifestation, role in the process of value formation, nature of participation in the process of value creation, belonging to the enterprise.

The International Standard on Integrated Reporting provides for the expediency of including in such reporting information about entity's natural capital. However, this document does not provide a clear algorithm for generating and presenting relevant information. The process of generating data on the natural capital of an enterprise, necessary for its evaluation, involves the following stages: creating a register of natural resources involved in value creation at the enterprise; determining the benefits of the enterprise generated by its natural resources; measuring the amount of benefits received in both natural and monetary measures; estimating the amount of costs of an enterprise related to the use of its natural resources; estimating the value of an entity's natural capital based on the determination of the discounted amount of the net benefit of the use of natural resources in the value creation process.

In order to properly identify the benefits of using the natural resources of the enterprise and objectively evaluate them, it is necessary to establish the 
correspondence between the individual types of these resources and the benefits generated by them. The use of natural resources of the enterprise necessitates the expenditure on maintenance, support and recovery, as well as compensation for damage caused to the environment. It is advisable to estimate the total amount of natural capital of an enterprise on the basis of discounting the average annual amount of the net expected benefit over the period of its natural resources' useful life in the process of value creation. Monetary valuation of individual elements and the total amount of natural capital of an enterprise will provide more objective coverage of their role in the value creation process and environmental impact, will increase their efficiency, reduce reputation risks for stakeholders and, therefore, improve resource potential and investment potential of the enterprises.

\section{References:}

Atkinson, G. 2015. Natural Capital and Economic Growth. Retrieved from: https://assets.publishing.service.gov.uk/government/uploads/system/uploads/attach ment_data/file/516948/ncc-discussion-paper-economic-growth-natural-capital.pdf.

Barker, R. 2017. How Should a «Sustainable Corporation» Account for Natural Capital? Retrieved from: https://corpgov.law.harvard.edu/2017/11/06/how-should-asustainable-corporation-account-for-natural-capital.

Bouleev, I.P., Rassuzhday, E.Ya. 2015. Methodical approaches to the assessment of the natural capital of a coal mining enterprise. Economic Bulletin of Donbass, 2(40), 416.

Burkinsky, B.V., Goryachuk, V.F. 2013. Assessment of natural capital of Ukrainian regions as a condition of formation of green economy. Economic Innovation: A Collection of Scientific Papers, 52, 9-20.

Costanza, R., Daly, H.E. 1992. Natural Capital and Sustainable Development. Conservation Biology, G(1), 37-46.

Czaja, St. 2013. Selected problems of methodical and methodological elements of the valuation of natural capital. Prace Naukowe Uniwersytetu Ekonomicznego we Wrocławiu, 317, 272-290.

DesRoches, C.T. 2018. What is Natural about Natural Capital during the Anthropocene. Retrieved from: https://ideas.repec.org/a/gam/jsusta/v10y2018i3p806-d136231.html.

DTEK company official website. 2018. Retrieved from: dtek.com/content/announces/-zvit2018-2_pdf_s957_t2846.pdf.

Economic valuation and its applications in natural capital management and the Government's 25 Year Environment Plan. 2019. Retrieved from: https://assets.publishing.service.gov.uk/government/uploads/system/uploads/attach ment_data/file/608850/ncc-natural-capital-valuation.pdf.

Farley J. 2018. Natural Capital Retrieved from: http://www.uvm.edu/ jfarley/publications/Natural-Capital-Farley.pdf.

Fiedor, B. 2017. The nature and valuation of natural capital in terms of ecological economy. Prace Naukowe Uniwersytetu Ekonomicznego we Wrocławiu, 49, 136-145.

How Companies value Natural Capital. 2019. Retrieved from: http://www.naturalcapitalmarkets.org./uploads/media/GNF_How_ Companies_value_natural_capital.pdf.

Integrated Report 2016 company CLARIANT reports. 2016. Retrieved from: 
clariantn.com/2016/integrated-report/business-areas/care-chemicals.html.

Integrated Report and Annual Financial Statements AECI GROUP. 2015. Retrieved from: https://www.aeciworld.com/report/ar_2015/gog-natural.pdf.

Kriven, O. 2006. Natural capital in the system of economically-balanced economics formation (Ph.D). I. Franko National University, Ukraine.

Lushchik, M. 2019. Slowing down the use of natural resources as a challenge for the modern economy. Retrieved from: http://ur.edu.pl/pliki/Zeszyt16/34.pdf.

Malyha, N.M. 2010. Natural capital: identity and accounting area. Newsletter of economical science of Ukraine, 1(17), 66-71.

Melnyk, M.V., Kogdenko, V.G. 2016. Integrated Reporting Analysis: Natural Capital. Economic analysis: theory and practice, $4,72-84$.

Merafer company official website. 2017. www.meraferesourees.co.za/reports/ir_2017/natural-capital.php.

Shlapak, M.Yu. 2010. Natural capital as the basic understanding element of economic accounting. Regional economy, 2, 106-110.

The International Integrated Reporting Framework. 2013. Retrieved from: https://integratedreporting.org/wp-content/uploads/2013/12/13-12-08-THEINTERNATIONAL-IR-FRAMEWORK-2-1.pdf.

The depletion of natural capital will become one of the most acute business problems in the 21st century. 2020. Retrieved from: http://www.pr-release.ru/cat/news/49647.

Vegera, S. 2015. Natural capital in accounting: a recognized need. In Improving accounting, analysis and control as mechanisms of information support for sustainable economic development: Materials of the II International Scientific and Practical Conference, 196-201. Novopolotsk, PSU.

Veklic, O., Yahheva, T. 2004. Taking into account capital as the basic component of economic development of Ukraine. Economy of Ukraine, 12, 75-80. 